\title{
THE MOST NORTHERN RECORD OF GERVAIS' BEAKED WHALE, MESOPLODON EUROPAEUS (GERVAIS, 1855), FOR THE SOUTHERN HEMISPHERE
}

\author{
Aline M. A. Martins ${ }^{{ }^{*}}$, Tarcisio T. Alves Jr. ${ }^{1}$, Manuel A. A. Furtado Neto ${ }^{2}$ and Jon Lien ${ }^{3}$
}

\begin{abstract}
This paper reports the most northern record of Mesoplodon europaeus for the southern hemisphere based on a specimen of beaked whale that stranded on Bitupitá Beach (02 $\left.53^{\prime} 94^{\prime \prime} \mathrm{S} ; 41^{\circ} 16^{\prime} 41^{\prime \prime} \mathrm{W}\right)$, on the northeastern coast of Brazil, on 23 November 2001. Identification of this individual was based on the position of the two mandibular teeth in the lower jaw. The teeth were flattened laterally, embedded in the lower jaw at the mandibular symphysis, and located posterior to the middle of the jaw. Until recently, the distribution of this species was considered limited to the northern hemisphere of the Atlantic Ocean, based on the occurrence of stranding events and sightings. The presence of M. europaeus at lower latitudes in the southern hemisphere, and the relatively fresh condition of this carcass suggest the possible existence of a broad twohemisphere distribution the Atlantic Ocean.
\end{abstract}

Resumo - Este trabalho apresenta o registro mais setentrional da espécie Mesoplodon europaeus para o Atlântico Sul Ocidental baseado no encalhe de um espécime na Praia de Bitupitá (02 $53^{\prime} 94^{\prime \prime} \mathrm{S} ; 41^{\circ} 16^{\prime} 41^{\prime \prime} \mathrm{W}$ ), no litoral nordeste do Brasil, em 21 de Novembro de 2001. A identificação do animal encalhado foi baseada na posição e nas características dos dois dentes encontrados na mandíbula. Os dentes, achatados lateralmente, se inserem na altura da sínfise mandibular, localizando-se posteriormente ao meio da mandíbula. Dados recentes, baseados em encalhes e avistagens consideram a distribuição desta espécie limitada ao Atlântico Norte. Com presença de espécimes de M. europaeus encalhados em bom estado de conservação em latitudes mais austrais, é possível sugerir uma distribuição mais ampla desta espécie, abrangendo os dois hemisférios do Oceano Atlântico.

Keywords: Ziphiidae, Mesoplodon europaeus, Gervais' Beaked Whale, strandings, distribution, northeastern Brazil.

\section{Introduction}

Beaked whales (family Ziphiidae) are a poorly described group of cetaceans. Currently, knowledge regarding their biology has been gleaned from stranded specimens with a few documented sightings. Recently, due to increased effort, relatively more strandings have been recorded (MacLeod, 2000). There are 21 beaked whale species currently recognized, but new species of the genus Mesoplodon still are being described, such as Mesoplodon perrini (Dalebout et al., 2002), or redescribed, such as Mesoplodon traversii (van Helden et al., 2002).

Ziphiids are rarely observed at sea due to their preference for deep ocean waters and their cryptic appearance when surfacing (Dalebout et al., 2002). There are a few records of live sightings in North Carolina, USA (Tove, 1995), and in Caribbean waters (Rosario-Delestre et al., 1999). However, the exact distribution of the genus Mesoplodon remains poorly known and until recently, some authors suggested that inferences of distribution based on strandings might reflect strays from the normal range (Mead, 1989; Martin et al., 1990).

The Gervais' beaked whale, Mesoplodon europaeus, seems to be limited to tropical and warm temperate waters of the Atlantic, and is generally associated with North Atlantic coasts where occurrences are most frequently recorded (Leatherwood and Reeves, 1983; Martin et al., 1990). This is likely due to cetacean studies in the northern hemisphere have been conducted for a longer time and by the higher number of research groups when compared to those in the southern hemisphere. Compared to other species of beaked whales of the genus Mesoplodon that regularly occur in the North Atlantic, M. europaeus has been reported to occur further south, with possible distribution across the equator (MacLeod, 2000).

Most records for $M$. europaeus have been made in western North Atlantic waters from New York to Texas (over 40 published records, Mead, 1989). Several other occurrences of $M$. europaeus have been reported for eastern Atlantic coasts, including its holotype (Gervais, 1855), which was found in the English Channel in 1848 (Martin et al., 1990). Stranding records also are reported for the northwest shores of Ireland (Bruton et al., 1989), the coast of Portugal in Playa de Inatel (Castells and Mayo, 1992), in southern Spain (Valverde and Galan, 1996), and an unpublished stranding in France (MacLeod, 2000).

Seven individuals of M. europaeus have also been reported stranded on different occasions from 1985 - 1989 in the Canary Islands (Martin et al., 1990). Reiner (1980) found a skull of an individual from this species in Guinea Bissau. A carcass of a female was found in Mauritania, West Africa, in 1992 (Robineau and Vely, 1993).

In the Caribbean Islands, there are records from the Bahamas - one skull in East Plana Key in 1981 (Annon. in Mead, 1989), and photograph records of a male found in Mira Por Vos Cays (Balcomb, 1981). The first record in Cuba was made by Aguayo (1954) and several others were subsequently recorded by Varona $(1970,1985)$. Records from Jamaica include a lactating female with a female fetus (Rankin, 1953). Cadwell (1964) described an individual that

\footnotetext{
${ }^{1}$ Associação de Pesquisa e Preservação de Ecossistemas Aquáticos (AQUASIS). SESC Iparana, Praia de Iparana, s/n, Caucaia, CE 61600-000 Brazil.

${ }^{2}$ Universidade Federal do Ceará, Departamento de Engenharia de Pesca. Campus do Pici s/n, Fortaleza, CE 60035-000 Brazil.

${ }^{3}$ Memorial University of Newfoundland, Whale Research Group. A1C 5S7 St. John's, Newfoundland, Canada.

*Corresponding author: alinebrxn@yahoo.com.
} 
stranded in Montego Bay in 1963, also in Jamaica. Fraser (1955) described a skull and vertebrae from Trinidad. The latest occurrence is a specimen stranded in Cousin's Cove, in 1993, but only its total length was recorded (RosarioDelestre et al., 1999). Villalba-Cisneros (1986) recorded the first stranding of M. europaeus in the Dominican Republic in 1986. Recently, Rosario-Delestre and colleagues (1999) recorded two stranded specimens in the U.S. Virgin Islands - one specimen in the Cayman Islands, and live sightings in Anegada Passage in the northeast Caribbean Sea.

In the southern Atlantic Ocean, there are three records for Ascension Island $\left(7^{\circ} 45^{\prime} \mathrm{S} 14^{\circ} 30^{\prime} \mathrm{W}\right)$, in the central Atlantic. The first record was a male; the second was a female carrying a male fetus, stranded in Georgetown (Mead, 1989). The third was an unpublished stranding recorded in Ascencion Island in March 2002, in which a recently dead male was found near Georgetown (Richard White, Ascension Conservation Office, pers. comm.). These cases provide support for re-examining the hypothesis that this species occurs along the central South Atlantic.

A recent stranding of a Gervais' beaked whale in São Vicente ( $23^{\circ} 58^{\prime} S$; $46^{\circ} 24^{\prime} \mathrm{W}$ ), São Paulo state, Brazil, was reported. This was considered the southernmost record for the species in the South Atlantic Ocean and the first known from the Brazilian as well as the entire southwest Atlantic coast (Santos et al., 2003).
This paper reports the most northern record of M. europaeus in the southern hemisphere.

\section{Methods}

In the present study, the identification of the specimen (AQUA 211) was based on morphological characteristics of the skull, mandibles and teeth - the only parts of the animal that were recovered. The skull and mandible were then buried at the stranding site (soft beach sand and high temperature) and marked for later recovery. Based on our previous efforts, we found this procedure provided a reliable cleaning method, as soft tissue attached to bones are easily removed without impacting the cranial structures. After three months the bones were recovered, cleaned, and measured with a caliper to the nearest $0.1 \mathrm{~mm}$.

\section{Results and Discussion}

The animal stranded on 23 November 2001 on Bitupitá beach $\left(02^{\circ} 53^{\prime} 94^{\prime \prime} \mathrm{S} ; 41^{\circ} 16^{\prime} 41^{\prime \prime} \mathrm{W}\right)$ on the northeastern coast of Brazil (Figure 1). The specimen stranded dead in a fresh condition, as described by local fishermen. Fishermen filleted the animal and salted the meat to be used later for their own consumption.

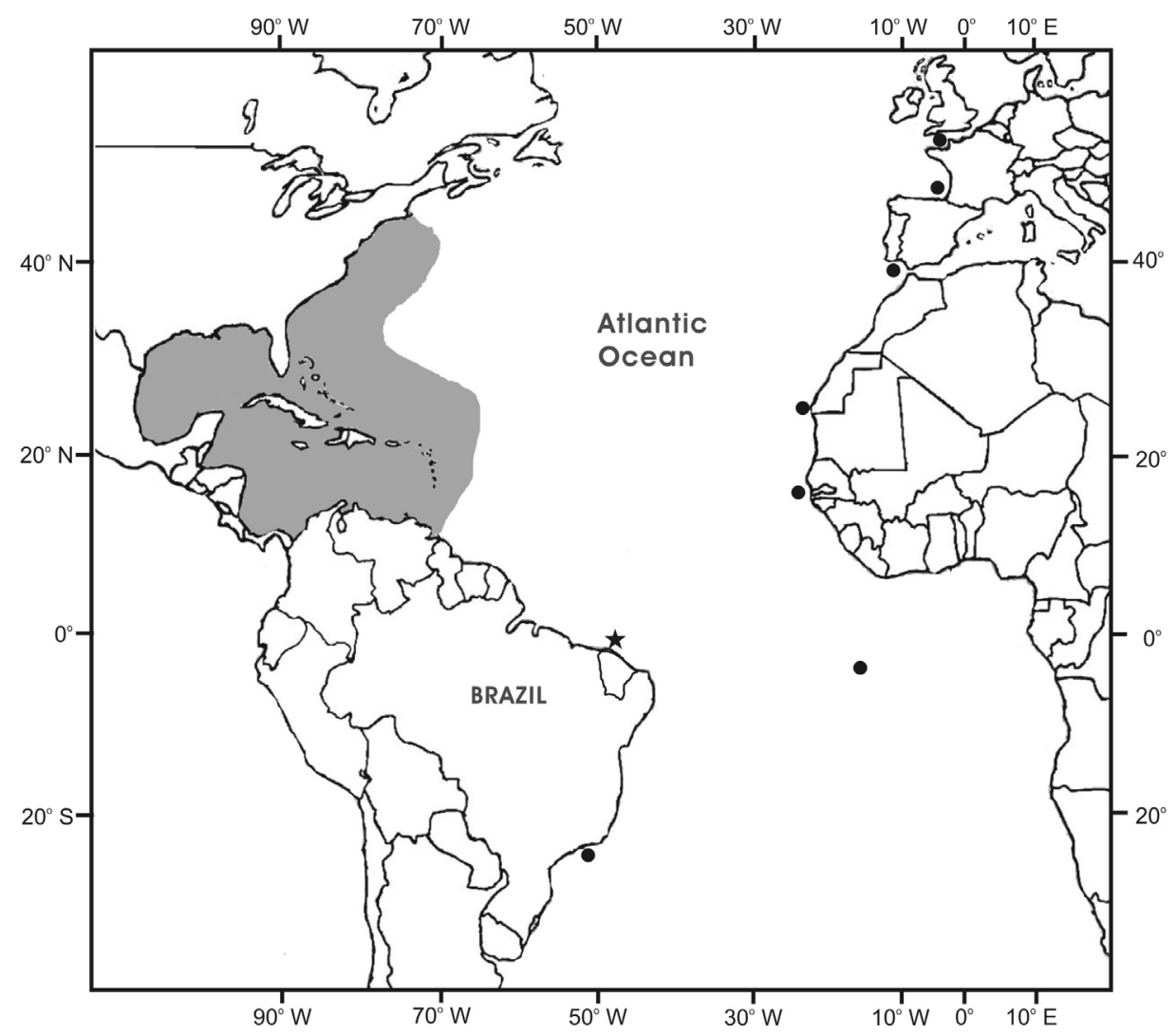

Figure 1. Distribution of Mesoplodon europaeus in the Atlantic Ocean. The shaded area along the western Atlantic Ocean represents the distribution of the species according to Mead (1989). Black circles show the previous strandings and sightings records of M. europaeus along the eastern Atlantic Ocean, as compiled by Norman and Mead (2001) and Santos et al. (2004). The black star indicates the record of M. europaeus stranded on the coast of Ceará state, northeastern Brazil (present study). Map adapted from Norman and Mead (2001). 
Species identification was based on the position of the two teeth in the lower jaw (Figures 2A and 2C), as well as through cranial measurements. The flattened laterally shape of the teeth (Figure 2D) at mandibular symphysis, posteriorly located at middle length in the lower jaw (Figure 2C), supported the identification (Raven, 1937; Rankin, 1956; Jefferson and Schiro, 1997). Additionally, the measurements of teeth and length of mandibular symphysis accounted for the correct identification of the specimen as M. europaeus. All measurements were taken according to Ross (1984) and are shown in Table 1.

Within the genus Mesoplodon, M. europaeus can be differentiated from other species by some features of the skull. M. europaeus and M. mirus can be differentiated by the shape of rostrum, which is more smooth at the maxillary prominence in the former species (Figure 2A). In M. mirus, this intersection forms an angular notch instead (Moore and Wood, 1957; Norman and Mead, 2001). Additionally, this species also displays the teeth more posteriorly located when compared to M. mirus (Rankin, 1956).

Cranial similarities may occur in two other species, $M$. bidens and M. grayi. However, according to Robineau and Vely (1993), they can be distinguished from M. europaeus, where lateral edges of the rostrum are slightly convex in dorsal view, and the lower contour shows a concave aspect in anterior portion and convex in posterior portion the lateral-view (Figure 2B). These features can be seen on the skull analyzed in the present study and are very helpful for species diagnosis based on cranial morphology.

The mesorostral groove was completely unfilled and there was no secondary ossification on its anterior extremity (Figure 2A), indicating an immature individual of $M$. europaeus (Raven, 1937). This conclusion is supported by the condylo-basal length $(\mathrm{CBL}=680 \mathrm{~mm})$, the rounded aspect of the occipital area, and the absence of ossification between the lateral region of the supraoccipital and parietals. The delicate condition of the basiocciptal suture also indicates immaturity (Rankin, 1956). In addtion, the pulp cavities of both teeth were not completely filled.

Until recently, the distribution of this species was considered limited to the North Atlantic Ocean, with random records along its known range that were assumed to be stray events. However, the number of records from Ascencion Island cannot be considered out-of-range events and MacLeod (2000) has suggested that the species' distribution may cross the Equator. The recent stranding of a young male M. europaeus in Ascencion Island (Richard White, pers. comm.) supports the hypothesis of a twohemisphere distribution within the Atlantic Ocean. Thus, the presence of M. europaeus in southern latitudes and the relatively fresh conditions of the carcass constitute

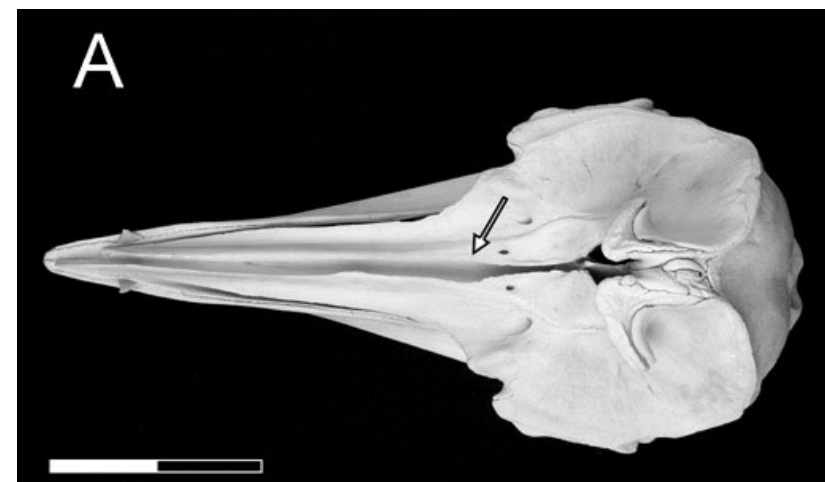

$20 \mathrm{~cm}$

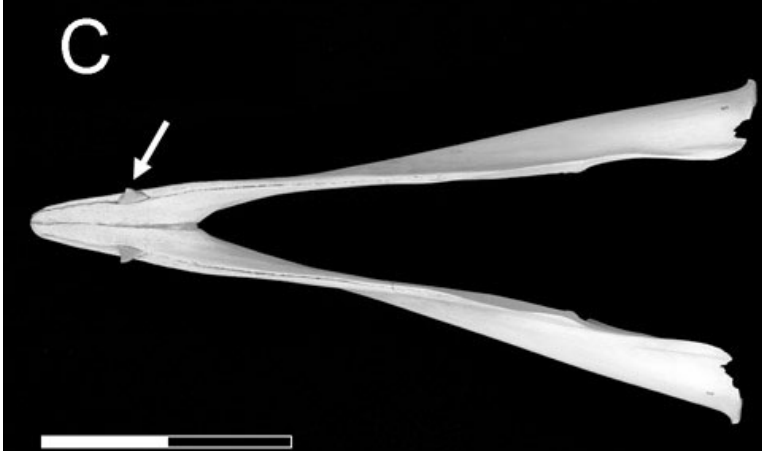

$20 \mathrm{~cm}$

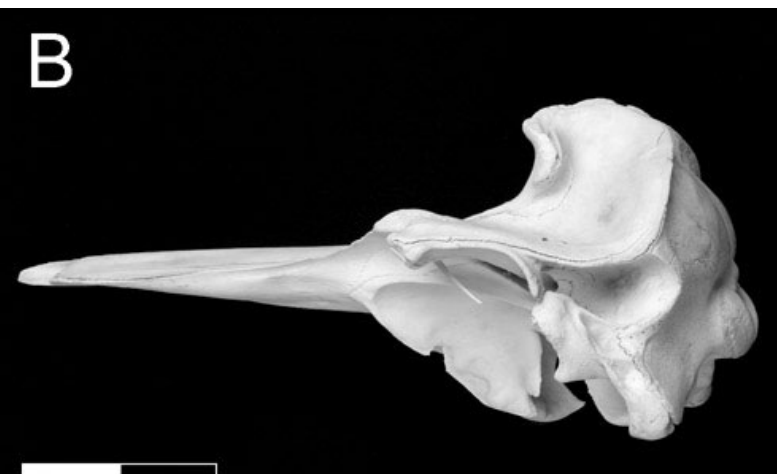

$20 \mathrm{~cm}$

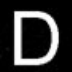

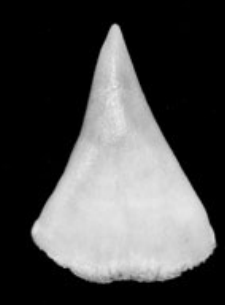

$3 \mathrm{~cm}$

Figure 2. (A) Dorsal view of skull with arrow showing the mesorostral groove; (B) Lateral view of skull; (C) Dorsal view of the lower jaw with arrow showing the position of the teeth at mandibular symphysis; (D) Teeth. Photos: Gentil Barreira ${ }^{\circledR} 2004$. 
Tabela 1. Cranial measurements of a specimen of M. europaeus stranded in northeastern Brazil.

\begin{tabular}{lrr}
\hline \hline MEASUREMENTS & $\mathrm{mm}$ & $\%$ \\
\hline \hline Condylobasal length (CBL) & 680 & 100.0 \\
Rostrum length & 420 & 61.7 \\
Rostrum width at midlength & 64 & 9.4 \\
Rostrum depth at midlength & 42 & 6.1 \\
Tip of rostrum to right pterygoid process & 351 & 51.4 \\
Height of skull (top of skull to pterygoids) & 275 & 40.3 \\
Breadth of skull across exocciptals & 210 & 30.7 \\
Breadth of skull across postorbital process of frontal & 319 & 46.7 \\
Breadth of skull across centers of orbits & 293 & 42.9 \\
Length of temporal fossa (right) & 62 & 9.1 \\
Width of temporal fossa (right) & 36 & 5.3 \\
Length of orbit (right) & 95 & 13.9 \\
Greatest span of premaxillary crests & 143 & 20.9 \\
Length of mandible (right) & 584 & 85.5 \\
Length of symphysis & 132 & 19.3 \\
Height of mandible at coronoid process (right) & 90 & 13.2 \\
Length of alveolus (right) & 29 & 4.2 \\
Width of alveolus (right) & 7 & 1.0 \\
Tip of mandible to anterior end of alveolus (right) & 76 & 10.0 \\
Tip of mandible to posterior end of alveolus (right) & 14.1 \\
Antero-posterior width of tooth (right) & 7 & 4.1 \\
Greatest breadth of tooth (right) & 1.0 \\
\hline \hline & & \\
\hline
\end{tabular}

evidence of cross equatorial distribution. Our stranding confirms the assumption of Santos et al. (2003) that Gervais' beaked whales may occur along the northeastern coast of Brazil and adds to the paucity of data on the distribution of M. europaeus in the southern hemisphere.

\section{Acknowledgments}

Special thanks to Antonio Amancio and also to Aquasis' crew, who made this study possible. Dr. James Mead helped with the identification of this specimen and gave thoughtful attention to our many requests. Dr. William Perrin kindly provided recent literature. Dr. Hugo Castello and Dr. Marcela Junin helped with the identification of this specimen. Colin MacLeod made helpful comments about stranding events in southern oceans. Dr. Paulo Cascon made relevant comments to the later versions of this paper. Special acknowledgement is given to Dr. Cassiano Monteiro Neto who helped us at the start of this work. Colin MacLeod, Shirley Pacheco de Souza and Marcos César de O. Santos kindly reviewed this manuscript

\section{References}

Aguayo, C.G. (1954) Notas sobre los cetáceos de aguas cubanas. Circular del Museo y Biblioteca de Zoología 13: 1125-1126.

Balcomb, K. C. (1981) Ziphiid whales from the Bahamas. Bahamas Naturalist, Summer issue, 19-22.
Bruton, T.D., Cotton, D. and Enright, M. (1989) Gulf Stream beaked whale Mesoplodon europaeus (Gervais). Irish Naturalists' Journal 23: 156.

Caldwell, D.K. (1964) A new record for the beaked whale Mesoplodon europaeus from Jamaica. Caribbean Journal of Science 4: 547.

Castells, A. and Mayo, M. (1992) Relacion de citas de cetaceos (Mammalia, Cetacea) España y Portugal, Centro de Estudios de Mammiferos Marinos, Madrid 2:43-96.

Dalebout, M.L., Mead, J.G., Baker, C.S., Baker, A.N. and van Helden, A.L. (2002) A new species of beaked whale Mesoplodon perrini sp.n. (Cetacea: Ziphiidae) discovered through phylogenetic analyses of mitochondrial DNA sequences. Marine Mammal Science 18: 577-608.

Fraser, F.C. (1955) A skull of Mesoplodon gervaisi (Deslongchamps) from Trinidad, West Indies. Annual Magazine of Natural History 8: 624-630.

Gervais, F.L.P. (1855) "Histoire naturelle dês mammifères", vol. II. L. Curmer, Paris.

van Helden, A.L., Baker, A.N., Dalebout, M.L., Reyes, J.C., van Waerebeek, K. and Baker, C.S. (2002) Resurrection of Mesoplodon traversii (Gray, 1874), senior synonym of $M$. bahamondi Reyes, Van Waerebeek, Cárdenas and Yañez, 1995 (Cetacea: Ziphiidae). Marine Mammal Science 18: 609621.

Jefferson, T.A. and Schiro, A.J. (1997) Distribution of cetaceans in offshore Gulf of Mexico. Mammal Review 27: 27-50.

Leatherwood, S. and Reeves, R.R. (1983) The Sierra Club Handbook of Whales and Dolphins. Sierra Club Books, San Francisco, CA. 
MacLeod, D.C. (2000) Review of the distribution of Mesoplodon species (order Cetacea, family Ziphiidae) in the North Atlantic. Mammal Review 30: 1-8.

Martin, V., Vonk, R., Escorza, S. and Montero, R. (1990) Records of Gervais' beaked whale Mesoplodon europaeus on the Canary Islands. European Research on Cetaceans. Proceedings of the Fourth Annual Conference of the European Cetacean Society, Palma de Mallorca, Spain.

Mead, J.G. (1989) Beaked whales from the genus Mesoplodon. Pages 349-430 in Ridgway, S.H. and Harrison, R. (Eds) Handbook of Marine Mammals. Volume 4. Academic Press, London.

Moore, J.C. and Wood, F.G. (1957) Differences between the beaked whales Mesoplodon mirus and Mesoploson gervaisi. American Museum Natural History Novitates 1831: 1-25.

Norman, S.A. and Mead, J.G. (2001) Mesoplodon europaeus. Mammalian Species 688: 1-5.

Rankin, J.J. (1953) First record of the rare Beaked whale Mesoplodon europaeus Gervais from the West Indies. Nature 172: 873-874.

Rankin, J.J. (1956) The structure of the skull of the beaked whale, Mesoplodon gervaisi Deslongchamps. Journal of Morphology 99: 329-358.

Raven, H.C. (1937) Notes on the taxonomy and osteology of two species of Mesoplodon [M. europaeus (Gervais), M. mirus (True)]. American Museum Natural History Novitates 905: 1-30.

Reiner, F. (1980) First record of an Antillean beaked whale, Mesoplodon europaeus, Gervais 1855, from Republica Popular da Guinea-Bissau. Museum do Mar, Serie Zoologica 1: 1-8.

Tove, M. (1995) Live Sighting of Mesoplodon CF. M. mirus, True's Beaked Whale. Marine Mammal Science 11: 80-85.

Robineau, D. and Vely, M. (1993) Stranding of a specimen of Gervais' beaked whale (Mesoplodon europaeus) on the coast of West Africa (Mauritania). Marine Mammal Science 9: 438-440.

Rosario-Delestre, R.J., Rodríguez-Lópes, M.A., MignucciGiannoni, A.A. and Mead, J.G. (1999) New records of beaked whales (Mesoplodon spp.) for the Caribbean. Caribbean Journal of Science 35: 144-148.

Ross, G.J.B. (1984) The smaller cetaceans of the southeast coast of southern Africa. Annals of the Cape Province Museum (Natural History) 15: 173-410.

Santos, M.C.O., Zampirolli, E., de Castro, A.F.V. and Alvarenga, F.S. (2003) A Gervais' beaked whale (Mesoplodon europaeus) washed ashore in southeastern Brazil: extra limital record? Aquatic Mammals 29: 404-410. Valverde, J.A. and Galan, J.M. (1996) Zoological notes on a Mesoplodon europaeus (Gervais), Cetacea, Ziphioidea, stranded in Andaluccia. European Research on Cetaceans. Proceedings of the Tenth Annual Conference of European Cetacean Society, Lisbon, Portugal (unpublished) pp. 77-183.

Varona, L.S. (1970) Morfología externa y caracteres craneales de un macho adulto de Mesoplodon europaeus (Cetacea: Ziphiidae). Poeyana Serie A69: 1-17.

Varona, L.S. (1985) Modificaciones ontogénicas y dimorfismo sexual en Mesoplodon gervaisi (Cetacea: Ziphiidae). Caribbean Journal of Science 21: 27-37.

Villalba-Cisneros, A. (1986) Primer reporte de la ballena de pico de las Antillas, Mesoplodon europaeus (Cetacea: Ziphiidae) para la República Dominicana in Bonnelly-deCalventi, I. (Ed.) Informe sobre los recursos marinos de la República Dominicana con énfasis en los mamíferos marinos y su protección, Appendix V. Universidad Autónoma de Santo Domingo, Centro de Investigaciones en Biología Marina (CIBIMA), Santo Domingo, Dominican Republic (unpublished). 